\title{
ВПЛИВ ДЕМОГРАФІЧНОЇ ПОЛІТИКИ КИТАЮ НА РОДИННЕ ВИХОВАННЯ КИТАЙЦІВ
}

\author{
Хотченко I. A. \\ кандидат педагогічних наук, доцент кафедри педагогіки, методики та \\ менеджменту освіти, Українська інженерно-педагогічна академія, \\ м. Харків, Україна
}

У изій статті на прикладі закону про обмеження народжуваності в Китайській Народній Республіиі досліджено та доведено існування значного впливу демографічної політики на родинне виховання китайців за всіма його існуючими напрямами: фізичним, трудовим, моральним, релігійним, розумовим, естетичним та екологічним вихованням.

Ключові слова: родинне виховання, напрями родинного виховання, політика обмеження народжуваності, Китай.

This article examines and proves the existence of a significant impact of demographic policy on Chinese family upbringing in all its existing directions: physical, labor, moral, religious, mental, aesthetic and environmental education on the example of the birth control law in the People's Republic of China.

Key words: family upbringing, directions of family upbringing, birth control policy, China.

На думку синологів сьогодення та минулих часів родинне виховання в Китаї значним чином базується на соціокультурних традиціях китайського народу, сформованих упродовж тривалого часу існування цієї дивовижної країни, яку історики справедливо називають «колискою всієї цивілізації». Початок вивченню китайської сім’ї та особливостей виховання в ній поклали ще Конфуцій, Менцзи, Сюньцзи та їх послідовники. У новітні часи зазначені проблеми досліджують Шень Гуаньцюнь, Го Цицзя, Кун Течен та ін.

Безперечно, дослідження китайського досвіду родинного виховання потребує глибокого попереднього аналізу чинників його формування та розвитку. Метою цієї статті є вивчення та доведення існування значного впливу на розвиток напрямів родинного виховання в Китаї такого важливого чиннику, як демографічна політика країни на прикладі «політики однієї дитини».

3 початку 1970-х років уряд КНР продовжував посилювати заходи, націлені на зниження народжуваності та стимулювання пізнього всту- 
Розділ III. Історичні та порівняльні аспекти в теорії і практиці духовно-інтелектуального виховання й навчання

пу до шлюбу. По всій країні, навіть у найменших адміністративних одиницях, створювались органи планування народжуваності [2, с.155].

25 вересня 1980 року Центральний комітет Комуністичної партії Китаю направив відкритого листа членам партії, виклавши в ньому проєкт плану з контролю над народжуваністю. У цьому листі стверджувалося, що впроваджується нова демографічна політика Китаю, яка буде тимчасовою і триватиме 30 років. Відтак «політика однієї дитини» або «одна сім'я - одна дитина» розпочала своє існування [1, с.215].

Згідно з дослідженням Любові Калашник для більш якісного аналізу родинного виховання в Китаї слід ураховувати його основні напрями: трудове, фізичне, патріотичне, моральне, релігійне, розумове, естетичне, екологічне виховання [4, с.119].

Варто зазначити, що демографічна політика «одна сім'я - одна дитина» суттєво вплинула на майже всі основні напрями традиційного родинного виховання у сучасному Китаї.

Трудове виховання. Перша половина XX століття принесла низку випробувань у життя китайської нації (Сінхайська революція, зміна форми державного правління, Японо-китайська війна). Суворі умови життя вимагали від батьків залучати своїх дітей до тяжкої праці з раннього віку. Із приходом до влади Мао Цзедуна та проголошенням Китайської Народної Республіки життя простих китайців не стало більш легким. У закладах середньої та вищої освіти широко використовувалась дитяча праця. Фізичне навантаження на учнівську молодь відчутно знизилось тільки наприкінці минулого століття, чим завдячує прийняття закону про обмеження народжуваності. Так, політика «одна сім'я - одна дитина».

Фізичне виховання. У цьому напрямі родинного виховання із прийняттям політики обмеження народжуваності також відзначаються певні зміни. Так, для підтримки здорового фізичного стану єдиної дитини у родині батьки починають більш активно заохочувати ії відвідувати спортивні секції, займатися фізичною культурою.

Патріотичне виховання. У китайських сім'ях дітям прищеплюють любов до матері, родини, рідного краю, свого народу, його культури та мови. Кожний китаєць цінує свою сім'ю, домашнє вогнище, Батьківщину. Дітей навчають поважати і зберігати традиції, цінувати речі вітчизняного виробництва. Проте, із прийняттям політики однієї дитини 
у родині посталі дві проблеми, що йшли всупереч принципам патріотичного виховання. Перша, — зріст відтоку учнівської молоді за кордон, котрий зумовлений бажанням батьків надати найліпші умови для отримання освіти. Друга проблема — вимушений переїзд до інших країн з метою отримання освіти так званих «штрафних дітей». «Штрафні діти» — діти, що народжені, всупереч існуючій політиці обмеження народження [2, с.156]. Для таких кричущих випадків порушення закону уряд встановив високі штрафні санкції та диференційований підхід у питаннях здобуття освіти. Наприклад, оплата навчання у закладі вищої освіти «штрафних дітей» складала величезні суми. Тому батькам було більш логічно інвестувати такі великі гроші в освіту своєї дитини за кордоном.

Моральне виховання. Характерною рисою морального виховання в китайській родині є довіра. Дитина з раннього віку привчається покладатися на власні сили. Однак цей напрям родинного виховання також не оминув вплив запровадження політики однієї дитини у родині. Надмірна увага, зростаючі вимоги й очікування батьків від єдиного нащадка подекуди стали провокацією для дітей. Так, з метою запобігання батьківського гніву діти були вимушені стати більш «гнучкими» у своїх моральних принципах, наприклад, практикуючі приховування правдивих фактів, обман тощо.

Релігійне виховання. Цей напрям є винятковим у черзі напрямів родинного виховання, оскільки не зазнав суттєвих змін.

Важливо зазначити, що особлива увага у китайській сім'ї завжди приділялася розумовому вихованню підростаючого покоління.

У контексті даної статті слід підкреслити, що високий показник щільності населення безпосередньо впливає на життєдіяльність кожного мешканця. Наприклад, дуже непростим завданням у Китаї постає набуття статусу конкурентоспроможного фахівця на ринку праці країни. 3 цієї причини отримання освіти традиційно сприймається китайцями як «перепустка у життя». Упродовж багатьох століть освічена людина в Китаї мала певні привілеї, за умов сучасності наявність диплому про вищу освіту істотно підвищує шанси китайців на отримання бажаної роботи. А отже вступний іспит до закладів вищої освіти Китаю й нині вирішує подальшу долю молоді, тому більшість випускників шкіл вбачає своє становлення як особистості тільки за умови отримання вищої освіти [3, с.41]. 
Розділ III. Історичні та порівняльні аспекти в теорії і практиці духовно-інтелектуального виховання й навчання

Китайські батьки є вельми прагматичними у відношенні до життя. Ця властивість ще більш загострилась за умов можливості мати тільки одну дитину, тому діти змушені поступатися власними інтересами, віддаючи перевагу відвідуванню тільки тих позашкільних заходів, які стануть у нагоді у поточному та подальшому навчанні. Таким чином, у напрямі розумового виховання спостерігається негативний вплив політики обмеження народжуваності: емоційний тиск з боку батьків, надмірне розумове навантаження, відсутність нормованого відпочинку, неможливість обрати позашкільні заходи за власним інтересом тощо.

Останніми двома напрямами родинного виховання є естетичне та екологічне виховання. В основі сучасної теорії і практики естетичного виховання у Китаї лежать давні історичні традиції, вони є сталими і не відчули на собі значного впливу політики обмеження народжуваності. Стосовно екологічного виховання також можна сказати про відсутність прямого впливу політики однієї дитини у родині на зміни пріоритетів у цьому напрямі для підростаючого покоління.

Отже, у даній статті досліджений та доведений значний, як позитивний, так і негативний вплив демографічної політики Китаю «одна сім'я - одна дитина» на родинне виховання китайців, яке охоплює такі важливі, пов'язані між собою напрями, як: фізичне, трудове, моральне, релігійне, розумове, естетичне та екологічне виховання.

\section{Список використанних джерел:}

1. Баженова, Е. С. Население Китая в эпоху модернизации и экономических реформ. Проблемы Дальнего Востока. 2009. № 5. С. 212-229.

2. Баженова Е. С. Новые тенденции в области социально-демографической политики в КНР. КНР: институционализация опыта реформ. Материалы ежегодной конференции Центра современной истории и политики Китая ИДВ РАН, 3 марта 2010 г. Информационные материалы. Серия В. Общество и государство в Китае в период реформ. Вып. 25. М.: 2010. C. $154-162$.

3. Дьячков С. Китайская грамота, или пять телег мудрости. Алма матер. 2001. №1. C.40-42.

4. Калашник Л. С. Педагогічні засади родинного виховання в китайській сім'ї [Текст] : дис... канд. пед. наук: 13.00.01; Харківський національний педагогічний ун-т ім. Г. С. Сковороди. Х., 2005. 220 арк. 